\title{
Comparison of Free and Immobilized L-asparaginase Synthesized by Gamma-Irradiated Penicillium cyclopium
}

\author{
HEBA A. EL-REFAI ${ }^{1 \star}$, MONA S. SHAFEI ${ }^{1}$, HANAN MOSTAFA ${ }^{1}$, ABDEL-MONEM H. EL-REFAI $^{1}$, \\ EMAN M. ARABY ${ }^{2}$, FAWKIA M. EL-BEIH ${ }^{3}$, SAADIA M. EASA ${ }^{3}$ and SANAA K. GOMAA ${ }^{1}$ \\ ${ }^{1}$ Chemistry of Natural and Microbial Products Department, National Research Center, Dokki, Cairo, Egypt \\ ${ }^{2}$ Microbiology Department, Egyptian Atomic Energy Authority, Cairo, Egypt \\ ${ }^{3}$ Microbiology Department, Faculty of Science, Ein-Shams University, Cairo, Egypt
}

Submitted 22 February 2015, revised 29 August 2015, accepted 31 August 2015

\begin{abstract}
Gamma irradiation is used on Penicillium cyclopium in order to obtain mutant cells of high L-asparaginase productivity. Using gamma irradiation dose of $4 \mathrm{KGy}$, P. cyclopium cells yielded L-asparaginase with extracellular enzyme activity of $210.8 \pm 3 \mathrm{U} / \mathrm{ml}$, and specific activity of $752.5 \pm 1.5 \mathrm{U} / \mathrm{mg}$ protein, which are 1.75 and 1.53 times, respectively, the activity of the wild strain. The enzyme was partially purified by $40-60 \%$ acetone precipitation. L-asparaginase was immobilized onto Amberlite IR-120 by ionic binding. Both free and immobilized enzymes exhibited maximum activity at $\mathrm{pH} 8$ and $40^{\circ} \mathrm{C}$. The immobilization process improved the enzyme thermal stability significantly. The immobilized enzyme remained $100 \%$ active at temperatures up to $60^{\circ} \mathrm{C}$, while the free asparaginase was less tolerant to high temperatures. The immobilized enzyme was more stable at $\mathrm{pH} 9.0$ for $50 \mathrm{~min}$, retaining $70 \%$ of its relative activity. The maximum reaction rate $\left(\mathrm{V}_{\max }\right)$ and Michaelis-Menten constant $\left(\mathrm{K}_{\mathrm{m}}\right)$ of the free form were significantly changed after immobilization. The $\mathrm{K}_{\mathrm{m}}$ value for immobilized $\mathrm{L}$-asparaginase was about 1.3 times higher than that of free enzyme. The ions $\mathrm{K}^{+}, \mathrm{Ba}^{2+}$ and $\mathrm{Na}^{+}$showed stimulatory effect on enzyme activity with percentages of $110 \%, 109 \%$ and $106 \%$ respectively.
\end{abstract}

Key words: Penicillium cyclopium, Amberlite IR-120, gamma irradiation, ionic binding immobilization, L-asparaginase

\section{Introduction}

The enzyme L-asparaginase (ASN) (EC.3.5.1.1; L-asparagine aminohydrolase) catalyzes the deamination of L-asparagine (Asn) to L-aspartate and ammonia. The enzyme is isolated from several sources: animal and plant cells, yeast, fungi, and bacteria, with a wide variety of microbial strains producing it (Gulati et al., 1997). L-asparaginase received increased attention in recent years as a food processing aid which reduces the formation of acrylamide in starch-based food that is baked, roasted or fried (Tareke et al., 2002).

It has been identified as an effective agent in the treatment of certain types of lymphoma and leukemia. Its use in anti-cancer therapy is based on its ability to cleave L-asparagine, an amino acid essential for the growth of lymphoblasts, to ammonia and L-aspartic acid in serum and cerebrospinal fluid. Since lymphoblasts are unable to produce endogenous L-asparagine, starvation for this amino acid leads to the death of these cells (Kotzia and Labrou, 2007).
The enzyme produced by Escherichia coli and Erwinia carotovora was clinically used to treat patients suffering from asparaginase-dependent leukemia (acute lymphoblastic leukemia) and lymphomas (Keating et al., 1993). A number of undesirable side effects were observed in cases of acute lymphoblastic leukemia, which were attributed to the contamination of enzyme preparations with bacterial endotoxins. The search for other asparginase sources such as eukaryotes, can lead to an enzyme with less adverse effects. It has been observed that eukaryote microorganisms such as yeast and filamentous fungi e.g. Aspergillus, Penicilliumm and Fusarium have a potential for asparaginase production (Sarquis et al., 2004).

Immobilization of enzymes is one of the important trends in biotechnology. The use of immobilized enzymes lowers production costs as these can be readily separated from the reaction mixture and can hence be used repeatedly and continuously (Maysa et al., 2010). Native L-asparaginase is often chemically modified and physically embedded with various kinds of soluble

* Corresponding author: H.A.El-Refai, Chemistry of Natural and Microbial Products Department, National Research Center, Dokki, Cairo, Egypt; e-mail: dr.heba_ar@yahoo.com 
and insoluble biocompatible polymers in order to produce immobilized L-asparaginase. It has been reported that the immobilized enzyme not only reduces toxicity, but also greatly improved resistance to proteolysis compared to native L-asparaginase (Zhang et al., 2004; Ghosha et al., 2011). Attempts were made for the preparation of insoluble matrix supports such as collagen (Jefferies et al., 1977), carboxy methyl cellulose (Hasselberger et al., 1970), polyacrylamide and poly (2-hydroxyethyl methacrylate) gels (O'Driscoll et al., 1975) derivatives bioconjucated with L-asparaginase for use in cancer therapy. That said, enzyme immobilization has attracted great interest by chemists and biochemists for its wide application in academic research and industrial processes (Mahmoud and Helmy, 2009; Shafei et al., 2015).

This research applied partial purification and immobilization of gamma-irradiated Penicillium cyclopium in order to improve the stability of L-asparginase for the effective mitigation of acrylamide formation in industrially processed and home-cooked high heat-treated potato products. The work was extended to compare between the kinetic parameters such as $\mathrm{pH}$, thermal stability, $\mathrm{K}_{\mathrm{m}}$ and $\mathrm{V}_{\max }$ of L-asparginase in its native and immobilized forms.

\section{Experimental}

\section{Materials and Methods}

Chemicals. All the chemicals used in this study are of analytical grade unless otherwise stated. Dowex, duolite, chitosan, cellulose, silica gel were purchased from Fluka company, Switzerland; Amberlite IR-120 from Fine-Chem Ltd. Boisar; and L-asparagine from Merck Company.

Microorganism. P. cyclopium was obtained from the culture collection of the National Research Center, Dokki, Cairo, Egypt. The stock culture was maintained on agar slopes that contained potato dextrose agar medium (PDA) at $30^{\circ} \mathrm{C}$ and preserved at $-80^{\circ} \mathrm{C}$ in $50 \%$ $(\mathrm{v} / \mathrm{v})$ glycerol with regular monthly transfer.

Enzyme production. P. cyclopium was incubated at $30^{\circ} \mathrm{C}$ for 3 days on a rotary shaker $(200 \times \mathrm{g})$ using a medium of the following composition $(\mathrm{g} / \mathrm{l})$ : sucrose, 2; L-asparagine, 10.0; $\mathrm{NH}_{4}\left(\mathrm{SO}_{4}\right), 8.77 ; \mathrm{KH}_{2} \mathrm{PO}_{4}, 1.52$; $\mathrm{KCl}, 0.52 ; \mathrm{MgSO}_{4} \cdot 7 \mathrm{H}_{2} \mathrm{O}, 0.52$; and $\mathrm{Cu}\left(\mathrm{NO}_{3}\right)_{2} \cdot 3 \mathrm{H}_{2} \mathrm{O}$, $\mathrm{ZnSO}_{4} 7 \mathrm{H}_{2} \mathrm{O}$ and $\mathrm{Fe} \mathrm{SO}_{4} \cdot 7 \mathrm{H}_{2} \mathrm{O}$ as trace elements (El Refai et al., 2014). Fresh fungal spores were used as inoculums and $1 \mathrm{ml}$ spore suspension (containing around $10^{6}$ spores $/ \mathrm{ml}$ ) was added to the sterilized medium and incubated at $30^{\circ} \mathrm{C}$ containing $100 \mathrm{ml}$ of the sterile medium. The $\mathrm{pH}$ of the medium was initially adjusted at $\mathrm{pH} 6.2$ in reciprocal shaker. At the end of the incubation period, the mycelia were removed by centrifugation $(5000 \times \mathrm{g})$ for $20 \mathrm{~min}$ at $4^{\circ} \mathrm{C}$. Proteins in the filtrate were precipitated by $60 \%$ acetone. This partially purified enzyme (specific activity $2120.8 \mathrm{U} / \mathrm{mg}$ protein) was used for the determination of L-asparaginase activity.

Enzyme assay. L-asparaginase activity of culture filtrate was determined by quantifying the ammonia formation using Nessler's reagent (Usha et al., 2011). One unit (IU) of L-asparaginase activity is defined as the amount of enzyme which liberates $1 \mu \mathrm{mol}$ of ammonia per minute ( $\mu \mathrm{mole} / \mathrm{ml} / \mathrm{min})$ under the standard assay conditions.

Protein determination. The protein content was determined according to Lowry method (1951) using bovine serum albumin as standard.

\section{Mutagenesis of P. cyclopium isolates by gamma irradiation}

Effect of $\boldsymbol{\gamma}$-irradiation on P.cyclopium. P. cyclopium was cultivated on potato dextrose agar plates and incubated at $30^{\circ} \mathrm{C}$ for 7 days. The developed colonies were scraped off and suspended in sterile saline solution. Spore suspension in triplicates was irradiated using $\mathrm{Co}^{60}$ gamma source according to Iftikhar et al. (2010), and radiation doses of 0.5-6.0 KGy in 0.5 KGy intervals were applied. As control, the number of colony-forming unit $(\mathrm{CFU} / \mathrm{ml})$ prior to irradiation was determined upon culturing on potato dextrose agar plates, as well as the number of survivors after exposure to different radiation doses.

Viable count determination. Ten-fold serial dilutions of irradiated spore suspension of P.cyclopium along with the control (non-irradiated) were prepared, and $0.1 \mathrm{ml}$ of each appropriate dilution was plated onto sterile potato dextrose agar media. The plates were incubated at $30^{\circ} \mathrm{C}$ for $24 \mathrm{~h}$, and the count of survived colonies as well as the initial one were determined. A dose response curve was plotted using the resulting counts. The sublethal dose and the $\mathrm{D}_{10}$ value for the strain were also calculated.

Effect of $\boldsymbol{\gamma}$-irradiation on $\mathrm{L}$-asparaginase activity. After exposure of spore suspension of P. cyclopium to gamma radiation, each test tube was inoculated in the basal medium and the flasks were incubated at $30^{\circ} \mathrm{C}$ for 3 days. $\mathrm{L}$-asparaginase activity for each irradiated dose was estimated as explained above, and the results were compared to those of the control (irradiated).

\section{Immobilization methods}

Physical adsorption. Enzyme immobilization using physical adsorption was done using alumina, polyvinyl alcohol and silica gel, prepared according to Abdel-Naby et al. (1998). One hundred milligrams of the carriers were incubated with $2.545 \mathrm{U}$ of $60 \%$ acetone enzyme fraction 
dissolved in $1 \mathrm{ml}$ of $0.1 \mathrm{M}$ Tris-HCL buffer ( $\mathrm{pH}$ 8.0) at $4^{\circ} \mathrm{C}$ overnight. The unbound enzyme was removed by washing with Tris- $\mathrm{HCl}$ buffer (0.1 M, pH 8.0).

Ionic binding. Ionic binding was used to achieve enzyme immobilization using $0.2 \mathrm{~g}$ of the cation (Dowex-50w, Amberlite IR-120) or anion exchanger (DEAE-cellulose) equilibrated with $0.1 \mathrm{M}$ acetate buffer $(\mathrm{pH} 8)$ or $0.1 \mathrm{M}$ Tris-HCL buffer $(\mathrm{pH} 8)$ respectively, and incubated with $5 \mathrm{ml}$ partially purified enzyme containing $2545 \mathrm{U}$ in the same buffer at $40^{\circ} \mathrm{C}$ for $24 \mathrm{~h}$. The unbound enzyme was removed by washing with the same buffer.

Covalent binding. For enzyme immobilization using covalent binding, $0.4 \mathrm{~g}$ of chitosan was shaken in $5 \mathrm{ml}$ of Tris-HCL and $0.1 \mathrm{M}$ buffer ( $\mathrm{pH} 8$ ) containing $2.5 \%(\mathrm{~V} / \mathrm{V})$ glutaraldehyde (GA) for $24 \mathrm{~h}$ at $30^{\circ} \mathrm{C}$. The solubilized chitosan was precipitated by the addition of $1 \mathrm{ml}$ of $0.1 \mathrm{M} \mathrm{NaOH}$. The precipitate was collected by filtration and washed with distilled water to remove excess GA. The wet chitosan was mixed with $1 \mathrm{ml}$ partially purified enzyme (2545 U). After being shaken for $1 \mathrm{~h}$ at $30^{\circ} \mathrm{C}$, the unbound enzyme was removed by washing with distilled water.

Immobilization yield (U/g carrier). Immobilization yield was calculated according to the following equation:

\section{Properties of the free and immobilized L-asparaginase}

Optimum pH. The effect of $\mathrm{pH}$ on the free and immobilized L-asparaginase was studied using citratephosphate buffer (0.1 M pH 3.0-7.0), and Tris-HCL buffer (0.1 M, pH 8.0-10.0).

Optimum temperature. The effect of temperature was studied by incubating both the free and immobilized enzymes in their respective optimum $\mathrm{pH}$ at different temperatures (ranging from 25 to $70^{\circ} \mathrm{C}$ ), with different controls, for 20 min using $2.0 \% \mathrm{~L}$-asparagine as substrate.

Thermal and $\mathrm{pH}$ stability of L-asparaginase. The thermal stability of L-asparaginase was investigated by incubating the free and immobilized enzyme at various temperatures $\left(30-80^{\circ} \mathrm{C}\right)$ with different incubation periods $(15,30,45$ and $60 \mathrm{~min})$ in absence of the substrate. The relative activities were then determined. For $\mathrm{pH}$ stability, the free and immobilized enzymes were incubated using different $\mathrm{pH}$ buffers for different time intervals (30 and $60 \mathrm{~min}$ ) after which the residual enzyme activity was determined.

Activation energy (Ea). The activation energy was determined using the slope of a linear plot of the log of the enzyme activity (v) versus $1 / \mathrm{T}$. The enzyme activity (v) was expressed in $U$ ( $\mu$ g protein $)^{-1}$, the temperature (T) in Kelvin (K), the gas constant $(\mathrm{R})=1.987 \mathrm{cal} \mathrm{K}^{-1}$ $\mathrm{mol}^{-1}$ and the activation energy (Ea) in $\mathrm{kcal} \mathrm{mol}^{-1}$.
Substrate concentration and determination of $\mathrm{K}_{\mathrm{m}}$ and $\mathrm{V}_{\text {max }}$. The effect of incubating different concentrations of L-asparagine $(0.02-0.12 \mathrm{mM})$ with the free or immobilized enzyme at $40^{\circ} \mathrm{C}$ for $30 \mathrm{~min}$, was investigated by estimating the residual enzyme activity. The initial velocity was measured as a function of substrate concentration and plotted as double reciprocals in accordance with the line-weaver-Burk analysis (Lineweaver and Burk, 1934). The $\mathrm{K}_{\mathrm{m}}$ and $\mathrm{V}_{\max }$ values were $0.0259 \mathrm{mM}$ and $757.6 \mathrm{U} / \mathrm{mg}$ protein for the free enzyme, and $0.033 \mathrm{mM}$ and $581 \mathrm{U} / \mathrm{mg}$ protein for the immobilized enzyme.

Effect of metal ions and EDTA on L-asparaginase activity. For determining the effect of some metal ions on L-asparaginase activity, the partially purified and immobilized enzyme were preincubated with $10^{-3} \mathrm{M}$ of $\mathrm{Na}^{+}, \mathrm{K}^{+}, \mathrm{Ba}^{2+}, \mathrm{Ca}^{2+}, \mathrm{Fe}^{2+}, \mathrm{Hg}^{2+}, \mathrm{Mn}^{2+}$ and EDTA for $2 \mathrm{~h}$ at $30^{\circ} \mathrm{C}$ and the residual activity was determined.

Statistical analysis. All experiments were repeated three times. Data provided in the corresponding tables and figures represent the mean values of the results obtained, along with the relative standard deviations.

\section{Results and Discussion}

Effect of $\gamma$-radiation on the survival of $P$. cyclopium. P. cyclopium strain was exposed to different doses of $\gamma$-radiation ranging from 0.5 to $6.0 \mathrm{KGy}$ at $0.5 \mathrm{KGy}$ interval. The number of viable cells decreased exponentially with increasing radiation dose. The $\mathrm{D}_{10}$ value was $2.5 \mathrm{KGy}$ and the sublethal dose was found to be $6.0 \mathrm{KGy}$.

Production of L-asparaginase by mutant gammairradiated P. cyclopium. The potential improvement of L-asparaginase production in $\gamma$-irradiated P. cyclopium was studied. Table I shows that L-asparaginase activity

\section{Table I}

Influence of $\mathrm{Co}^{60}$ gamma irradiation at various doses on L-asparaginase activity

\begin{tabular}{|c|c|c|c|}
\hline $\begin{array}{c}\text { Recovered } \\
\text { activity (\%) }\end{array}$ & $\begin{array}{c}\text { Specific activity } \\
(\mathrm{U} / \mathrm{mg} \text { protein })\end{array}$ & $\begin{array}{c}\text { L-asparaginase } \\
\text { activity (U/ml) }\end{array}$ & $\begin{array}{c}\text { Dose } \\
(\text { KGy })\end{array}$ \\
\hline 100 & $400 \pm 0.6$ & $160 \pm 1$ & Control \\
\hline $33 \pm 1.5$ & $294.4 \pm 3$ & $53 \pm 2.5$ & 0.5 \\
\hline $46 \pm 1$ & $389.5 \pm 0.5$ & $74 \pm 2.6$ & 1 \\
\hline $49.7 \pm 0.9$ & $397.5 \pm 4$ & $79.5 \pm 1.6$ & 1.5 \\
\hline $57.9 \pm 0.9$ & $421.4 \pm 2.5$ & $92.7 \pm 2.5$ & 2 \\
\hline $62.9 \pm 1$ & $437.8 \pm 2$ & $100.7 \pm 0.5$ & 2.5 \\
\hline $93.7 \pm 1.5$ & $441.4 \pm 3.3$ & $150 \pm 2.9$ & 3 \\
\hline $122.2 \pm 0.8$ & $651.7 \pm 1.3$ & $195.5 \pm 1.4$ & 3.5 \\
\hline $131.6 \pm 0.9$ & $752 \pm 1.5$ & $210.8 \pm 3$ & 4 \\
\hline $65.9 \pm 0.4$ & $363.4 \pm 1.8$ & $105.4 \pm 2.8$ & 4.5 \\
\hline $34.8 \pm 0.5$ & $289.5 \pm 2.4$ & $55 \pm 2.9$ & 5 \\
\hline
\end{tabular}


and specific activity increased with increasing the dose of gamma radiation. They both reached a maximum $210.8 \pm 3 \mathrm{U} / \mathrm{ml}$ and $752.5 \pm 1.5 \mathrm{U} / \mathrm{mg}$ protein at dose level $4 \mathrm{KGy}$. This was 1.75 times more for asparaginase activity, and 1.53 times more for specific activity of the wild strain. Similar results were obtained by ElBatal et al. (2000) and Fadel and El-Batal (2000). This enhancement by gamma radiation may be either due to an increase in gene copy number or gene expression or both (Rajoka et al., 1998). Several studies recorded that low doses of gamma radiation may stimulate microbial growth and metabolic activities. Meanwhile, high doses of gamma radiation were proved to be inhibitory for both growth and enzymatic activities of microorganisms. The exposure of cells to ionizing radiation sets off a chain of reactions giving rise to chemical and then to metabolic or physiological changes. The irradiation presents an additional stress to the cells which tends to disturb their organization. Irradiation effects have been shown to occur with proteins, enzymes, nucleic acid, lipids and carbohydrates, all of which may have marked effects on the cell (Ismail et al., 2010).

Partial purification of P. cyclopium L-asparaginase. The crude enzyme of the $\gamma$-irradiated P.cyclopium was subjected to purification (Table II). Both the enzyme activity and the specific activity of the partially purified asparaginase were increased to 3.0 fold and $2120.8 \mathrm{U} / \mathrm{mg}$ protein respectively.

Immobilization of P.cyclopium L-asparaginase using different carriers. The partially purified enzyme was dialysized, lyophilized and immobilized. Different immobilization techniques were investigated: physical adsorption, covalent binding and ionic binding. Results are presented in Table III. The highest loading efficiency $(1200 \pm 1.1 \mathrm{U} / \mathrm{g}$ carrier) and immobilization yield $(80 \pm 0.2 \%)$ were detected with ionic binding technique using Amberlite IR-120 which is a strongly acidic cation exchange resin suitable for a wide variety of chemical process applications. The least enzyme activity $(200 \mathrm{U} / \mathrm{g}$ carrier) and immobilization yield (11\%) were detected with covalent binding using Duolite 147 as a carrier. Therefore, Amberlite IR-120 proved to be the most appropriate carrier and was used in the succeeding work. Abdel-Naby et al. (1998) found that Amberlite IR-120 was a good carrier for Bacillus mycoides alkaline protease ionic binding. Also, Spinelli et al. (2013) stated that the use of low-cost matrices such as Amberlite IR-120 for enzyme immobilization represents a promising product for enzymatic industrial applications. On the contrary, Sundaramoorthi et al. (2012) showed that the highest enzyme immobilization activity and highest immobilization yield were achieved by the cross-linking technique using silica gel.

Optimum $\mathrm{pH}$ for free and immobilized enzymes. Both free and immobilized P. cyclopium L-asparaginase preparations exhibited maximum relative activity at pH 8.0 (Fig. 1). The immobilized form showed better relative activities across different $\mathrm{pH}$ levels ranging from 3.0 to 10.0. Dramatic decrease in relative activity (55-45\%) was observed for the free enzyme at $\mathrm{pHs} 9$

Table II

A profile of partial purified P. cyclopium L-asparaginase.

\begin{tabular}{|l|c|c|c|c|c|c|}
\hline \multicolumn{1}{|c|}{ Purification steps } & $\begin{array}{c}\text { Protein of } \\
\text { fraction }(\mathrm{mg} / \mathrm{F})\end{array}$ & $\begin{array}{c}\text { Recovered } \\
\text { protein }(\%)\end{array}$ & $\begin{array}{c}\text { Total activity } \\
(\mathrm{U} / \mathrm{ml})\end{array}$ & $\begin{array}{c}\text { Recovered } \\
\text { activity }(\%)\end{array}$ & $\begin{array}{c}\text { Specific activity } \\
(\mathrm{U} / \mathrm{mg} \text { protein })\end{array}$ & $\begin{array}{c}\text { Purification } \\
\text { Fold }\end{array}$ \\
\hline Culture filtrate & $28 \pm 0.3$ & 100.00 & $210.8 \pm 3.7$ & 100.0 & $750 \pm 2.8$ & 1.0 \\
\hline Precipitation by $40-60 \%$ acetone & $1.2 \pm 0.2$ & $4.3 \pm 0.7$ & $2545 \pm 4.5$ & $12 \pm 0.05$ & $2120.8 \pm 0.9$ & $3 \pm 0.1$ \\
\hline
\end{tabular}

Table III

Different immobilization methods of P. cyclopium L-asparaginase.

\begin{tabular}{|l|l|c|c|c|c|}
\hline $\begin{array}{c}\text { Method } \\
\text { of immobilization }\end{array}$ & \multicolumn{1}{|c|}{ Carrier } & $\begin{array}{c}\text { Added Enzyme } \\
\text { (U/g carrier) } \\
\text { A }\end{array}$ & $\begin{array}{c}\text { Unbound Enzyme } \\
\text { (U/g carrier) } \\
\text { B }\end{array}$ & $\begin{array}{c}\text { Immobilized enzyme } \\
\text { (U/g carrier) } \\
\text { I }\end{array}$ & $\begin{array}{c}\text { Immobilization } \\
\text { yield } \\
\text { (I/A-B) x100 }\end{array}$ \\
\hline \multirow{4}{*}{ Physical adsorption } & Alumina & 2545 & $603.8 \pm 0.9$ & $700 \pm 2$ & $36.1 \pm 0.2$ \\
\cline { 2 - 6 } & P.V.A & 2545 & $241.5 \pm 1.3$ & $328.1 \pm 2$ & $14.2 \pm 0.1$ \\
\cline { 2 - 6 } & silica gel & 2545 & $633.9 \pm 2.1$ & $800 \pm 3$ & $41.8 \pm 1.2$ \\
\hline \multirow{4}{*}{ Covalent binding } & Chitosan & 2545 & $682.5 \pm 1$ & $500 \pm 1.5$ & $26.8 \pm 3$ \\
\cline { 2 - 6 } & duolite-147 & 2545 & $301.9 \pm 1$ & $200 \pm 2$ & $11 \pm 0.25$ \\
\cline { 2 - 6 } & duolie-C280 & 2545 & $300 \pm 2.5$ & $450 \pm 2.6$ & $36.1 \pm 0.3$ \\
\hline \multirow{5}{*}{ Ionic binding } & Amberlite 120 & 2545 & $1045 \pm 2.6$ & $1200 \pm 1.1$ & $80 \pm 0.2$ \\
\cline { 2 - 6 } & Dowex 40-50 & 2545 & $656.3 \pm 2.4$ & $350 \pm 2.8$ & $18.5 \pm 1.5$ \\
\cline { 2 - 6 } & Dowex 50 & 2545 & $780 \pm 0.6$ & $250 \pm 0.6$ & $14 \pm 0.2$ \\
\cline { 2 - 6 } & Cellulose & 2545 & $600 \pm 1.5$ & $360 \pm 2.8$ & $18.5 \pm 0.3$ \\
\hline
\end{tabular}




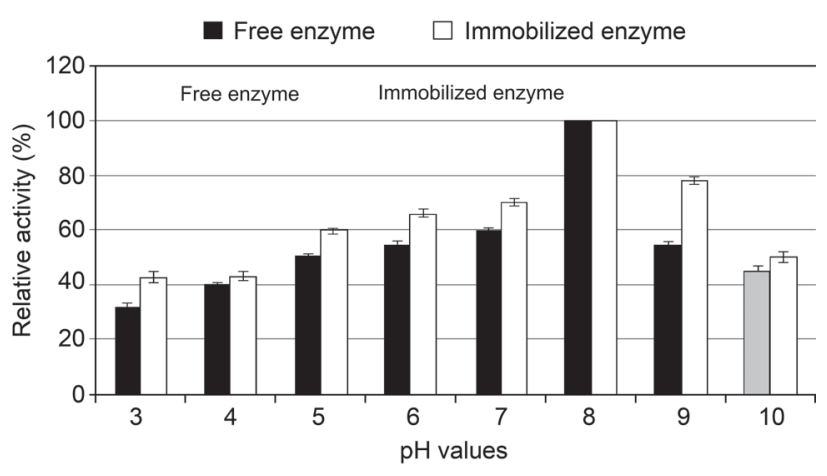

Fig. 1. Effect of $\mathrm{pH}$ values on the activities of the free and immobilized P. cyclopium L-asparaginase.

and 10 . This clearly reflects the suitability of Amberlite IR-120 as a carrier for this enzyme as $\mathrm{pH}$ varies. Tabandeh and Aminlari (2009) reported that the optimum activity of L-asparaginase is at the alkaline $\mathrm{pH}$ of 8 . This is probably due to the production of L-aspartic acid which acts as a competitive inhibitor for the enzyme under acidic conditions. Changes in $\mathrm{pH}$ activity behavior may be due to the immobilization of the enzyme, which could be explained by the unequal distribution of hydrogen and hydroxyl ions between the polyelectrolyte phase on which the enzyme is immobilized and the external solution (Kojima and Shimizu, 2003).

pH stability of free and immobilized L-asparaginase activity. The profile of $\mathrm{pH}$ stability (Table IV) showed that the immobilized L-asparaginase was more stable in a wider range of $\mathrm{pH}(3.0-6.0)$ during 30 and $60 \mathrm{~min}$ incubation compared to the free enzyme ( $\mathrm{pH} 3.0-4.0$ ), where it retained $100 \%$ of its relative activity. This result means that immobilized L-asparaginase would be more resistant to $\mathrm{pH}$ changes, hence could be used at the industrial level. The ionic binding technique using Amberlite IR-120 stabilizes the enzyme

Table IV

The $\mathrm{pH}$ stability of the free and immobilized P. cyclopium L-asparaginase.

\begin{tabular}{|c|c|c|c|c|}
\hline \multirow{4}{*}{$\begin{array}{c}\mathrm{pH} \\
\text { value }\end{array}$} & \multicolumn{4}{|c|}{ Relative activity (\%) } \\
\hline & \multicolumn{4}{|c|}{ Time of exposure } \\
\hline & \multicolumn{2}{|c|}{ Free } & \multicolumn{2}{|c|}{ Time of exposure } \\
\hline & $30 \mathrm{~min}$ & $60 \mathrm{~min}$ & $30 \mathrm{~min}$ & $60 \mathrm{~min}$ \\
\hline control & 100 & 100 & 100 & 100 \\
\hline 3 & 100 & 100 & 100 & 100 \\
\hline 4 & 100 & 100 & 100 & 100 \\
\hline 5 & 100 & $80 \pm 0.5$ & 100 & 100 \\
\hline 6 & $80 \pm 0.7$ & $75 \pm 1$ & 100 & 100 \\
\hline 7 & $72 \pm 0.5$ & $67.8 \pm 1.4$ & $95.7 \pm 0.3$ & $90 \pm 0.5$ \\
\hline 8 & $70 \pm 0.3$ & $60 \pm 1.1$ & $88 \pm 1.1$ & $80 \pm 1$ \\
\hline 9 & $60 \pm 0.5$ & $40 \pm 0.6$ & $86 \pm 1.5$ & $70 \pm 1.7$ \\
\hline 10 & $30 \pm 1.5$ & $20.5 \pm 0.5$ & $45 \pm 1.3$ & $28 \pm 0.5$ \\
\hline
\end{tabular}

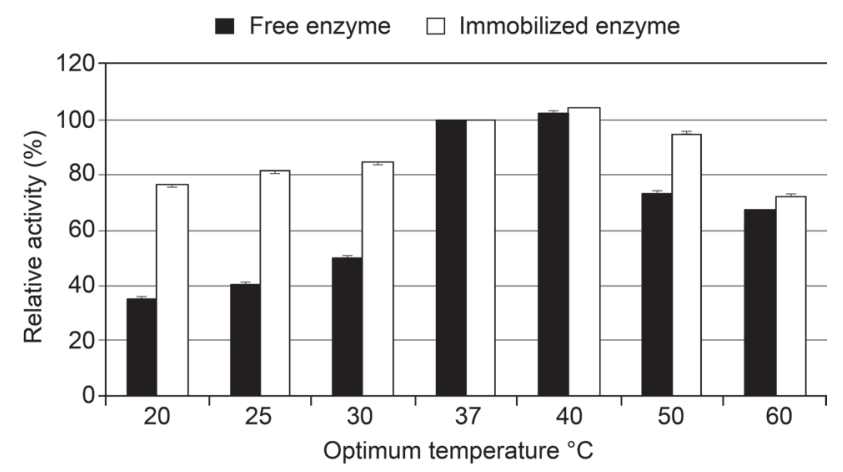

Fig. 2. Effect of temperature on the activities of the free and immobilized P. cyclopium L-asparaginase.

in acidic $\mathrm{pH}$, making it suitable for a wide variety of chemical process applications.

Optimum temperature. When profiling relative activity vs. reaction temperature, the optimum reaction temperature for maximal activity was apparently shifted to $40^{\circ} \mathrm{C}$ for the free and immobilized enzymes. Even though the reaction temperature rose to $60^{\circ} \mathrm{C}$, the relative activity of the immobilized enzyme was still above $72 \%$, while that of free $\mathrm{L}$-asparaginase was 66.7\% (Fig. 2). The temperature data were replotted in the form of Arrhenius plots. The plots of the immobilized and free enzymes were found to be linear, and the calculated values of Ea were 1.75 and $3.46 \mathrm{Kcal} /$ mol, respectively. The $\mathrm{E}_{\mathrm{a}}$ of asparaginase binding to Amberlite IR-120 was much lower than that of the free one, suggesting that the enzyme had significantly higher affinity to the Amberlite IR-120 active sites (Su et al., 2010). That said, the immobilization of the enzyme widened the optimum reaction temperature range (Zhang el al., 2004). Also, Youssef and Al-Omair (2008) reported that the optimum reaction temperature of immobilized asparaginase produced by E.coli was $60^{\circ} \mathrm{C}$ while that of free L-asparaginase was $50^{\circ} \mathrm{C}$.

Thermal stability for the free and immobilized P. cyclopium L-asparaginase. Heat stability of the free and immobilized L-asparaginase in terms of the residual activities was compared (Table V). The immobilized enzyme remained $100 \%$ active at temperatures up to $60^{\circ} \mathrm{C}$ for $30 \mathrm{~min}$ while the free asparaginase was $100 \%$ active up to $50^{\circ} \mathrm{C}$ for $30 \mathrm{~min}$. On the other hand, the effect of high temperatures $\left(50-80^{\circ} \mathrm{C}\right)$ was more pronounced in case of the free enzyme than the immobilized one, the later was more resistant to high temperatures compared to the free one. On the contrary, Zhang et al. (2004) reported that the thermostability of the immobilized L-asparaginase was very similar to that of the native enzyme, and that there were no obvious changes in the activities. On plotting log of the relative activity against time at different tested temperatures $\left(60,70\right.$ and $\left.80^{\circ} \mathrm{C}\right)$, both the free and the immobilized enzyme preparations gave straight lines (Fig. 3 and 


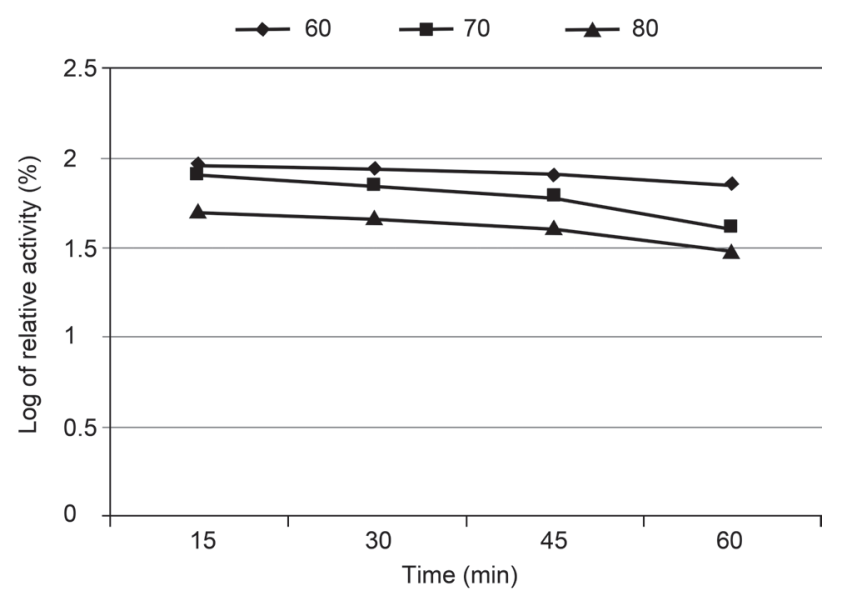

Fig. 3. First-order plots of thermal inactivation for the free P. cyclopium L-asparaginase activity.

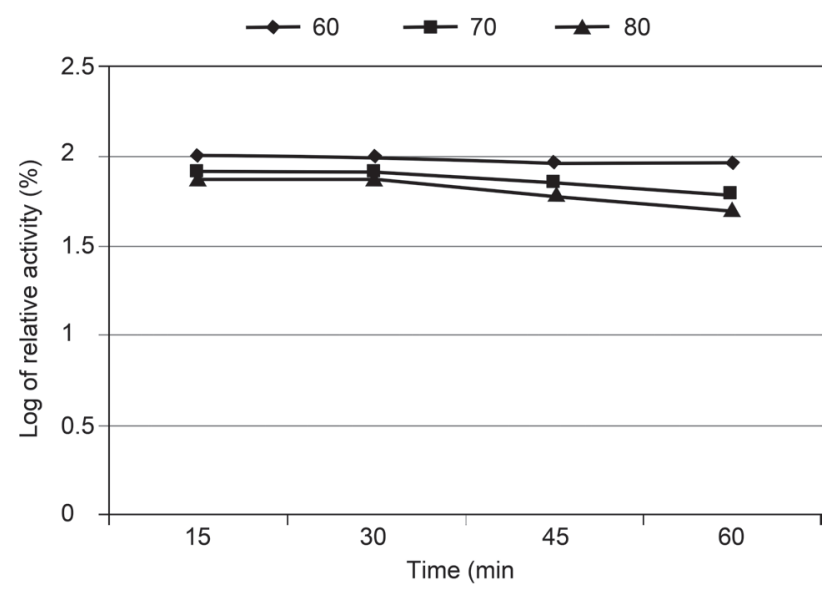

Fig. 4. First -order plots of thermal inactivation for the immobilized P. cyclopium L-asparaginase activity.

Fig. 4 respectively). This means that the thermal inactivation process of both enzyme forms corresponded to the theoretical curves of the first order reaction. The results showed that the immobilized enzyme was more thermostable than the free one. For example, the cal-

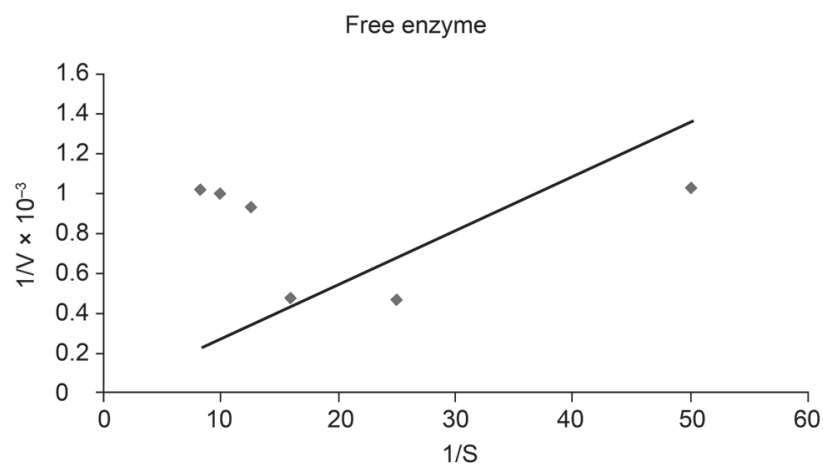

Fig. 5. Lineweaver - Burk plots for the free P. cyclopium L-asparaginase activity.

culated half-lives of the free enzyme at 60,70 and $80^{\circ} \mathrm{C}$ were 5.2, 3.6 and $2.47 \mathrm{hrs}$, respectively, proving to be lower than those of the immobilized enzyme, which were $10.4,4.26$ and $3.06 \mathrm{hr}$, respectively. The values of the deactivation rate constant (the slope of the relative activity) at increasing temperatures showed that the immobilized enzyme is highly stable compared to the free one. The calculated deactivation rate constants at 60,70 and $80^{\circ} \mathrm{C}$ for the free enzyme were $2.2 \times 10^{-3}$, $3.7 \times 10^{-3}$ and $5.3 \times 10^{-3}$, compared to $1.1 \times 10^{-3}, 2.7 \times 10^{-3}$ and $3.8 \times 10^{-3}$, respectively, for the immobilized enzyme.

Kinetics and hydrolysis. The Michaelis-Menten Kinetics of the hydrolytic activity of the free and immobilized L-asparaginase were investigated using varying initial concentrations of asparagine as a substrate. There was a parallel increase in the relative enzyme activities of the free and immobilized treatment and the substrate concentrations $(0.02-0.04 \mathrm{mM} / \mathrm{ml})$. The initial velocity was measured as a function of substrate concentration for both free and immobilized enzyme and plotted (Fig. 5 and Fig. 6 respectively) as double reciprocals in accordance with the line-weaver-Burk analysis (Lineweaver and Burk, 1934). The $\mathrm{K}_{\mathrm{m}}$ and $\mathrm{V}_{\max }$ values were $0.0259 \mathrm{mM}$ and $757.6 \mathrm{U} / \mathrm{mg}$ protein, respectively, for the free enzyme, and $0.033 \mathrm{mM}$ and

Table V

Thermal stability of the free and immobilized P. cyclopium L-asparaginase activity.

\begin{tabular}{|l|c|c|c|c|c|c|c|c|}
\hline \multirow{3}{*}{$\begin{array}{c}\text { Temperature } \\
{ }^{\circ} \mathrm{C}\end{array}$} & \multicolumn{7}{|c|}{ Fesidual activity (\%) } \\
\cline { 2 - 9 } & \multicolumn{8}{|c|}{ Time of exposure (min) } \\
\cline { 2 - 9 } & 15 & 30 & 45 & 60 & 15 & 30 & 45 & 60 \\
\hline Control & 100 & 100 & 100 & 100 & 100 & 100 & 100 & 100 \\
\hline 30 & 100 & 100 & 100 & 100 & 100 & 100 & 100 & 100 \\
\hline 40 & 100 & 100 & 100 & 100 & 100 & 100 & 100 & 100 \\
\hline 50 & 100 & 100 & $90 \pm 1.2$ & $80 \pm 1$ & 100 & 100 & 100 & 100 \\
\hline 60 & $90 \pm 1$ & $85.5 \pm 0.8$ & $80 \pm 1.2$ & $70 \pm 1.5$ & 100 & 100 & $90 \pm 0.5$ & $90 \pm 0.5$ \\
\hline 70 & $80 \pm 1.1$ & $70 \pm 0.6$ & $60 \pm 1$ & $40 \pm 0.5$ & $80 \pm 0.6$ & $80 \pm 0.6$ & $70 \pm 0.6$ & $60 \pm 1.7$ \\
\hline 80 & $50 \pm 1.1$ & $45.9 \pm 0.5$ & $39.9 \pm 0.5$ & $30 \pm 2.3$ & $73.9 \pm 1$ & $73.7 \pm 0.9$ & $60 \pm 1.7$ & $50.0 \pm 0.5$ \\
\hline
\end{tabular}




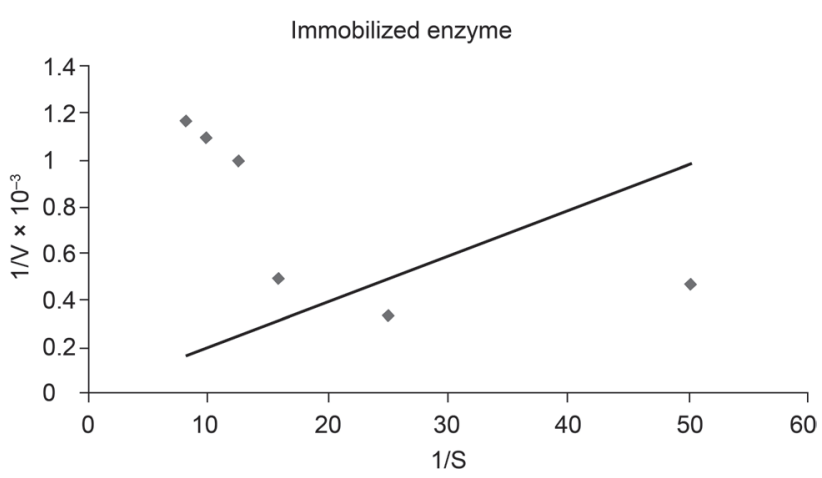

Fig. 6. Lineweaver - Burk plots for the immobilized P. cyclopium L-asparaginase activity.

$581 \mathrm{U} / \mathrm{mg}$ protein, respectively, for the immobilized enzyme. The $\mathrm{K}_{\mathrm{m}}$ value for immobilized L-asparaginase was about 1.3 times higher than that of the free enzyme, indicating a lower affinity towards the substrate. This increase in $\mathrm{K}_{\mathrm{m}}$ might be either due to the structural changes in the enzyme induced by the immobilization method, or due to the lower accessibility of the substrate to the active sites (Su et al., 2010). On the other hand, fixation of the enzyme on the immobilization matrix could lead to a decrease in the flexibility of the enzyme molecule, which is commonly reflected by a decrease in the catalytic activity (Cao, 2005). Consequently, the maximum rate of the reaction $\mathrm{V}_{\max }$ catalyzed by the immobilized enzymes was lower than that of the free enzyme, which was in agreement with $\mathrm{Su}$ et al. (2010). The ratio $\mathrm{V}_{\max } / \mathrm{K}_{\mathrm{m}}$ is a measurement of the catalytic efficiency of an enzyme-substrate pair. The catalytic efficiency of L-asparaginase was decreased by about $40 \%$ upon immobilization. Another important aspect to take into consideration in order to evaluate the immobilization process is the efficiency factor. This factor can be calculated from the higher reaction rates of the immobilized enzyme divided by that of the free counterpart. That said, the efficiency factor $=v_{\text {immobilized }} l$ $v_{\text {free }}$, where $v_{\text {immobilized }}$ is the reaction rate of the immobilized enzyme, and $v_{\text {free }}$ is that of the free enzyme. For $\mathrm{L}$-asparaginase, the efficiency factor was calculated to be 0.766 .

Effect of metal ions on L-asparaginase activity. In this experiment, both the free and immobilized enzymes were incubated with different metal ions in their salt solutions at room temperature for $30 \mathrm{~min}$ utes. Following this, the relative activity was measured at optimum conditions. The results show that $\mathrm{K}+\mathrm{Ba} 2+$ and $\mathrm{Na}+$ enhanced the enzyme activity with $110 \%, 109 \%$ and $106 \%$ respectively (Fig. 7 ). Considerable loss of activity was observed with $\mathrm{Mn}^{2+}$ and $\mathrm{Fe}^{3+}$. Inhibition of enzyme activity with EDTA by $61.9 \%$ possibly suggest that the purified L-asparaginase might be a metaloenzyme (Elshafei et al., 2012). However, the highest inhibition value was recorded with $\mathrm{Hg}^{2+}$ which

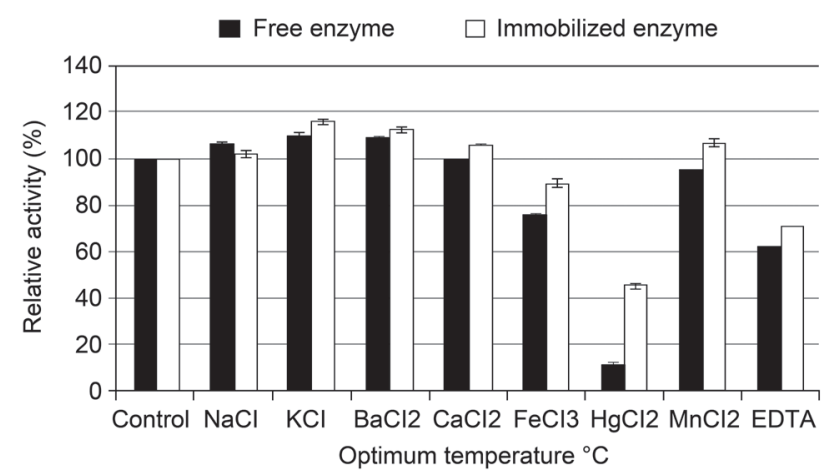

Fig. 7. Effect of different additives on activity of L-asparaginase of P. cyclopium.

inhibited the enzyme to $11 \%$. This might be indicative of essential vicinal sulfhydryl groups (SH-group) of the enzyme for productive catalysis (Elshafei et al., 2012). Similar results were reported by Basha et al. (2009) and Moorthy et al. (2010).

Conclusions. Our aim in this study was using gamma irradiation, purification, immobilization and characterization of L-asparaginase from P.cyclopium and to do a comparative study based on temperature, $\mathrm{pH}$, inhibitor and activation concentration between free and immobilized enzyme. Gamma irradiation proved to be effective in the production of L-asparaginase with a total increase in enzyme activity of 1.75 folds and specific activity of 1.53 folds over the wild strain. L-asparaginase was partially purified then immobilized onto Amberlite IR-120. The immobilized enzyme showed optimal activity over a wide range of temperature and $\mathrm{pH}$ values. The immobilized L-asparaginase widened the optimum reactive temperature range and showed higher thermostability as well as higher affinity to the substrate. Considering all these characteristics, the production of L-asparaginase from gamma irradiated immobilized P.cyclopium may be recommended for industrial production.

\section{Literature}

Abdel-Naby M.A., A-MS. Ismail, S.A. Ahmed and A.F. Abdel Fattah. 1998. Production and immobilization of alkaline protease from Bacillus mycoides. Bioresour. Technol. 64: 205-210.

Basha N.S., R. Rekha, M. Komala and S. Ruby. 2009. Production of extracellular anti-leukemic enzyme L-asparaginase from marine actinomycetes by solid state and submerged fermentation: Purification and characterization. Tropic. J. Pharm. Res. 8: 353-360.

Cao L. 2005. Carrier-bound Immobilized Enzymes: Principles, application and design. Wiley-VCH, Weinheim.

El-Batal A.I., M.A. Abo-State and A. Shihab. 2000. Phenylalanine ammonia lyase production by gamma irradiated and analogresistant mutants of Rhodotorula glutinis. Acta Microbiol. Pol. 49: 51-61.

Elshafei A.M., M.M. Hassan, M.A. Abouzied, D.A. Mahmoud and D.H. El-Ghonemy. 2012. Purification, Characterization and 
antitumor activity of L-asparaginase from Penicillium brevicompactum NRC 829. Brit. Microbiol. Rese. J. 2: 158-174.

El-Refai H.A., M.S. El-Shafei, H. Mostafa, A.H. El-Refai, F.M. El-Beih, G.E.A. Awad, S.M. Easa and S.K. Gomaa. 2014. Statistical optimization of anti-leukemic enzyme L-asparaginase production by Penicillium cyclopium. Curr. Trends. Biotechnol. Pharm. 8: 1-10.

Fadel M. and A.I. El-Batal. 2000. Studies on activation of amylolytic enzymes production by gamma irradiated Aspergillus niger using some surfactants and natural oils under solid state fermentation. Pak. J. Bio. Sci. 3: 1762-1768.

Gulati R., R.K. Saxena and R. Gupta. 1997. A rapid plate assay for screening L-asparaginase producing microorganisms. Lett. Appl. Microbiol. 24: 23-26

Ghosha S., S.R. Chagantib and R.S. Prakashamb. 2011. Polyaniline nanofiber as a novel immobilization matrix for the anti-leukemia enzyme l-asparaginase. J. Mol. Catal. B: Enzyme. 74: 132-137.

Hasselberger F.X., H.D. Brown, S.K. Chattopadhyay, A.N. Mather, R.O. Stasiw, A.B. Patel and S.N. Pennington. 1970. The preparation of insoluble, matrix-supported derivatives of L-asparaginase for use in cancer therapy. Cancer Res. 30: 2736-7368.

Iftikhar T., M. Niaz, Y. Hussain, S.Q. Abbas, I. Ashraf and Z.M. Anjum. 2010. Improvement of selected strains through gamma irradiation for enhanced lipolytic potential. Pak. J. Bot. 42: 2257-2267. Ismail A.A., E.S.A. El-Sayed and A.A. Mahmoud. 2010. Some optimal culture conditions for production of cyclosporin A by Fusarium roseum. Braz. J.Microbiol. 41: 1112-1123.

Jefferies S.R., R. Richards and F.R. Bernath. 1977. Preliminary studies with L-asparaginase bound to implantable bovine collagen heterografts, a potential long-term, sustained dosage, antitumor enzyme therapy system. Biomat. Med. Dev. Art Org. 5: 337-354.

Keating M.J., R. Holmes, S. Lerner and D.H. Ho. 1993. L-asparaginase and PEG asparaginase-past, present and future. Leuk. Lymphoma. 10: 153-157.

Kojima Y. and S.Shimizu. 2003. Purification and characterization of the lipase from Pseudomonas fluorescens HU380. J. Biosci. Bioeng. 96: 219-226

Kotzia G.A. and N.E. Labrou. 2007. L-asparaginase from Erwinia Chrysanthemi 3937, Cloning, expression and characterization. J.Biotechnol. 127: 657-669.

Lineweaver H. and D. Burk. 1934. The determination of enzyme dissociation constants. J. Am. Chem. Soc. 1: 658-666.

Lowry O.H., N.J. Rosebrough, A.L. Farr and R.J. Randall. 1951. Protein measurement with folin phenol reagent. J. Biol. Chem. 193: 265-275.

Mahmoud D.A. and W.A. Helmy. 2009. Potential application of immobilization technology in enzyme and biomass production. J. Appl. Sci. Res. 5: 2466-2476.
Moorthy V., A. Ramalingam, A. Sumantha and R.T. Shankaranaya. 2010. Production, purification and characterization of extracellular L-asparaginase from a soil isolate of Bacillus sp. Af. J. Microbiol. Res. 4: 1862-1867.

Maysa E.M., M. Amira, E. Gamal, T. Sanaa and E.I. Sayed. 2010. Production, immobilization and anti-tumor activity of L-asparaginase of Bacillus sp. R36. J. Amer. Sci. 6: 157-165.

O’Driscoll K.F., R.A. Korus, T. Ohnuma and I.M. Walczack. 1975. Gel entrapped L-asparaginase, kinetic behavior and antitumor activity. J. Pharmacol. Exp. Ther. 195: 382-388.

Rajoka M.I., A. Bashir, M.R.A. Hussain, M.T. Ghauri and K.A. Malik. 1998. Mutagenesis of Cellulomonas biazotea for improved production of cellulases. Folia. Microbiologica 43: 15-22.

Usha K., K.Mala, C.K. Venil and M. Palaniswamy. 2011. Screening of Actinomycetes from mangrove ecosystem for L-asparaginase activity and optimization by response surface methodology. Pol. J. Microbiol. 60: 213-221.

Sarquis M.I.M., E.M.M. Oliveria, A.S. Santos and G.L. da Costa. 2004. Production of L-asparaginase by filamentous fungi. Mem. Inst. Oswaldo. Cruz. 99: 489-492.

Shafei M.S., H.A. El-Refai, H. Mostafa, A.H. El-Refai, F.M. ElBeih, S.M. Easa and S.K. Gomaa. 2015. Purification, characterization and kinetic properties of Penicillium cyclopium L-asparaginase: Impact of L-asparaginase on acrylamide content in potato products and its cytotoxic activity. Curr. Trends. Biotechnol. Pharm. 9: 130-138. Spinelli D., E. Fatarella, A. Di Michele and R. Pogni. 2013. Immobilization of fungal (Trametes versicolor) laccase onto Amberlite IR-120 H beads: Optimization and characterization. Proc. Biochem. 48: 218-223.

Su E., T. Xia, L. Gao, Q. Dai and Z. Zhang. 2010. Immobilization and characterization of tannase and its haze-removing. Food Sci. Technol. Int. 15: 545-552.

Sundaramoorthi C., R. Rajakumari, D. Abhay and K. Venkadeshprabhu. 2012. Production and immobilization of l-asparaginase from marine source. Int. J. Pharma. Pharmaceut. Sci. 4: 229-232.

Tabandeh M.R. and M. Aminlari. 2009. Synthesis, physicochemical and immunological properties of oxidized inulin-l-asparaginase bioconjugate. J. Biotech. 141: 189-195.

Tareke E., P. Rydberg, P. Karlsson, S. Eriksson and M. Törnqvist. 2002. Analysis of acrylamide, a carcinogen formed in heated foodstuffs. J. Agric. Food Chem. 50: 4998-5006.

Youssef M.M. and A.M. Al-Omair. 2008. Cloning, purification, characterization and immobilization of $\mathrm{L}$-asparaginase from $E$. coli w3110. Asi. J. Biochem. 3: 337-350.

Zhang J.F., L.Y. Shi and D.Z. Wei. 2004. Chemical modification of L-asparaginase from Escherichia coli with a modified polyethyleneglycol under substrate protection conditions. Biotechnol. Lett. 26: 753-756. 